The Sense of Semblance 
This page intentionally left blank 


\section{The Sense of Semblance}

PH I L O O PH ICA L A N A Y SES

OF HOLOCAUST ART

Henry W. Pickford

FORdHAm University press New York 2013 


\section{$\mathrm{mL}$}

THIS BOOK IS MADE POSSIBLE BY A COLLABORATIVE GRANT

FROM THE ANDREW W. MELLON FOUNDATION.

\section{Copyright $\left(C_{2013}\right.$ Fordham University Press}

All rights reserved. No part of this publication may be reproduced, stored in a retrieval system, or transmitted in any form or by any means-electronic, mechanical, photocopy, recording, or any otherexcept for brief quotations in printed reviews, without the prior permission of the publisher.

Fordham University Press has no responsibility for the persistence or accuracy of URLs for external or thirdparty Internet websites referred to in this publication and does not guarantee that any content on such websites is, or will remain, accurate or appropriate.

Fordham University Press also publishes its books in a variety of electronic formats. Some content that appears in print may not be available in electronic books.

Library of Congress Cataloging-in-Publication Data

\section{Pickford, Henry W.}

The sense of semblance : philosophical analyses of Holocaust art / Henry W. Pickford.

pages $\mathrm{cm}$

Summary: "Drawing on work in contemporary analytic philosophy and Adorno's normative aesthetic theory, this book aims to show how selected Holocaust artworks in a variety of media (lyric poetry by Paul Celan, Holocaust memorials, quotational texts by Heimrad Bäcker, Claude Lanzmann's film Shoah and Art Spiegelman's graphic novel Maus) fulfill both aesthetic and historical requirements of the genre" - Provided by publisher.

Includes bibliographical references and index.

ISBN 978-0-8232-4540-6 (hardback)

I. Holocaust, Jewish (I939-I945), and the arts.

I. Title.

NXI80.H59.P53 20I3

$700 ' .4584053$ I 8 - dc23

Printed in the United States of America

I5 I4 I3 5432 I

First edition 
for my mother and in memory of my father 
This page intentionally left blank 